\title{
Salmonella typhi mutants defective in anaerobic respiration are impaired in their ability to replicate within epithelial cells
}

\author{
Inés Contreras, ${ }^{1}$ Cecilia S. Toro, ${ }^{2}$ Gonzalo Troncoso ${ }^{2}$ and Guido C. Mora ${ }^{2}$
}

\begin{abstract}
Author for correspondence: Guido C. Mora. Tel: +562222 4516. Fax: +5622225515. e-mail: gmora@genes.bio.puc.cl
\end{abstract}

1 Departamento de Bioquímica y Biología Molecular, Facultad de Ciencias Químicas y Farmacéuticas, Universidad de Chile, Casilla 174 Correo 22, Santiago, Chile

2 Unidad de Microbiología, Departamento de Genética Molecular y Microbiología, Facultad de Ciencias Biológicas, Pontificia Universidad Católica de Chile, Casilla 114-D, Santiago, Chile

\begin{abstract}
By using MudJ (Kan, lac)-directed operon fusion technology, mutants of Salmonella typhi whose gene expression is induced under anaerobic growth conditions were isolated. Characterization of their phenotypes and regulatory properties revealed that two of the mutants were unable to use nitrate as a terminal electron acceptor in the absence of oxygen, suggesting that they were defective in nitrate reductase activity. Anaerobic induction of these fusions did not further increase in response to nitrate. Strains carrying an additional mutation in oxr $A$ were constructed. They showed a lower level of $\beta$ galactosidase expression both aerobically and anaerobically; however, the ratios of anaerobic induction remained unaltered. These MudJ insertions mapped to the 17-19 min region of the chromosome. Based upon their phenotypes and mapping, one of the mutants probably possessed a modC (chID)::MudJ insertion and the other a moaA (chIA)::MudJ insertion. A third mutant was unable to use either nitrate or fumarate as a terminal electron acceptor. All three mutants showed a reduced ability to enter into and proliferate within HEp-2 epithelial cells. The oxrA mutation enhanced entry and proliferation of both the wild-type cells and the three mutants. Taken together, these results suggest that anaerobic respiration plays a role in $S$. typhi invasiveness.
\end{abstract}

Keywords: Salmonella typhi, anaerobiosis, nitrate respiration, invasiveness

\section{INTRODUCTION}

Salmonella typhi, the causal agent of typhoid fever, is a specific human pathogen. Fundamental for S. typhi infectivity is its capacity to cross the mucosa of the distal ileum, as well as to survive and multiply within macrophages (Di Rita \& Mekalanos, 1989; Finlay \& Falkow, 1989; Groisman \& Saier, 1990; Falkow et al., 1992). To persist and establish a successful infection, S. typhi must be able to adapt to the fluctuating environmental conditions encountered within the human host. There is a growing body of evidence showing that bacterial pathogens are constantly sensing their environment and adjusting to it by regulating the expression of several genes and operons. This response often involves changes in the expression of genes encoding virulence factors (Miller et al., 1989; Dorman, 1991; Falkow et al., 1992; Mekalanos, 1992).

One of the conditions encountered by S. typhi during invasion of the intestinal epithelium, as well as in tissues during systemic infection of the human host, is low oxygen availability (Lee \& Falkow, 1990), for which enteric bacteria have developed adaptive responses. Facultative anaerobes, such as Escherichia coli and Salmonella typhimurium, can grow under aerobic or anaerobic conditions, deriving energy from a variety of respiratory or fermentative processes. Aerobically, oxygen serves as a terminal electron acceptor. Anaerobically, alternative respiratory chain acceptors, such as nitrate, nitrite, fumarate or dimethylsulphoxide, can be utilized (Poole \& Ingledew, 1987; Lin \& Kuritzkes, 1987). Both global and specific regulatory systems have been implicated in the regulation of anaerobic gene expression, to ensure that the most energetically favourable metabolic process is adopted (Spiro \& Guest, 1991; Stewart, 1993; Guest, 1995).

There is evidence that oxygen availability may be an environmental signal controlling Salmonella virulence. It has been shown that anaerobiosis induces the invasion phenotype in S. typhimurium (Ernst et al., 1990; Schiemann \& Shope, 1991; Jones \& Falkow, 1994) as well as in S. choleraesuis and S. typhi (Lee \& Falkow, 
1990; Tartera \& Metcalf, 1993; Tartera et al., 1993). Two oxygen-regulated invasion loci, hil (Lee et al., 1992) and $\operatorname{org} A$ (Jones \& Falkow, 1994), required for $S$. typhimurium internalization into epithelial cells have been identified. However, their specific functions are unknown.

In a previous study we showed that the ability of $S$. typhi strain Ty2 to enter into and proliferate within HEp-2 epithelial cells was enhanced in anaerobically grown bacteria (Contreras et al., 1995a). To identify anaerobically induced genes required for the invasion and proliferation of $S$. typhi strain Ty2 in cultured cells, we isolated several MudJ operon fusions in oxygenregulated genes and characterized them as to their abilities to enter into and multiply within epithelial and phagocytic cell lines of human origin (Contreras et al., 1995a). In the present work we further characterize three of these anaerobically induced fusions. These mutants are defective in the nitrate respiratory system and they are impaired in their ability to proliferate within HEp- 2 cells. To our knowledge, the contribution of genes involved in anaerobic metabolism to the infectious capacity of facultative pathogens has not been reported previously.

\section{METHODS}

Bacterial strains, media and growth conditions. $S$. typhimurium strains MST1 (wild-type), TN3038 (chlC::MudA) and MST2970 (oxrA2::Tn10 leuBCD485) were obtained from S. Maloy, University of Illinois, Urbana, USA. S. typhimurium strain TT10269 (chlC1130::Tn10) was provided by J. Roth, The University of Utah, Salt Lake City, USA. S. typhi strain Ty2 (wild-type) was obtained from the Instituto de Salud Pública de Chile, Santiago, Chile, and $S$. typhi strain MCO01 (Ty2 MudI Mucts MudJ) was obtained in our laboratory (Contreras et al., 1994). The S. typhi insertion mutants described in this study and their properties are shown in Table 1. The complex medium used was Luria-Bertani broth (LB: Bacto tryptone, $10 \mathrm{~g} \mathrm{I}^{-1}$; Bacto yeast extract, $\left.5 \mathrm{~g} \mathrm{l}^{-1} ; \mathrm{NaCl}, 5 \mathrm{~g} \mathrm{l}^{-1}\right)$. The minimal medium was medium $\mathrm{E}$ $\left(\mathrm{MgSO}_{4} .7 \mathrm{H}_{2} \mathrm{O}, 0.02 \mathrm{~g} \mathrm{l}^{-1}\right.$; citric acid. $\mathrm{H}_{2} \mathrm{O}, 2 \mathrm{~g} \mathrm{l}^{-1} ; \mathrm{Na}_{2} \mathrm{HP}$ $\mathrm{O}_{4} \cdot 3 \mathrm{H}_{2} \mathrm{O}, 13 \cdot 1 \mathrm{~g} \mathrm{l}^{-1} ; \mathrm{NaNH}_{4} \mathrm{HPO}_{4} \cdot 4 \mathrm{H}_{2} \mathrm{O}, 3 \cdot 3 \mathrm{~g} \mathrm{l}^{-1}$ ) supplemented with cysteine $\left(50 \mathrm{mg} \mathrm{l}^{-1}\right)$ and tryptophan $\left(50 \mathrm{mg} \mathrm{l}^{-1}\right)$. Carbon sources were added to a final concentration of $0.2 \%$ $(w / v)$. Where indicated, sodium nitrate or sodium fumarate were added to a final concentration of $20 \mathrm{mM}$. Dimethylsulphoxide was added to a final concentration of $0.1 \%$ $(\mathrm{w} / \mathrm{v})$. Solid media contained $1.5 \%(\mathrm{w} / \mathrm{v}$ ) Bacto agar (Difco). When necessary, media were supplemented with kanamycin $\left(50 \mu \mathrm{g} \mathrm{ml}^{-1}\right)$. Chlorate resistance was assayed by scoring growth on medium $\mathrm{E}$ agar plates containing glucose, sodium nitrate and potassium chlorate $(15 \mathrm{mM})$ after incubation for $48 \mathrm{~h}$ under anaerobic conditions. Anaerobiosis was achieved by the use of GasPak anaerobic jars. Aerobic cultures $(5 \mathrm{ml})$ were incubated in $125 \mathrm{ml}$ flasks with vigorous shaking. Strains were grown at $37^{\circ} \mathrm{C}$.

Isolation of oxygen-regulated operon fusions. Random MudJ insertions in the $S$. typhi strain Ty 2 chromosome were obtained as previously described (Contreras et al., 1994). Briefly, a phage $\mathrm{Mu}$ lysate, obtained by heat induction (Bukhari \& Ljungquist, 1977), of S. typhi strain MCO01 was used to infect $S$. typhi strain Ty2 at an m.o.i of 0.01 p.f.u. per bacterium. After incubation for $20 \mathrm{~min}$ to allow phage adsorption followed by another $40 \mathrm{~min}$ with shaking in the presence of $15 \mathrm{mM}$ EDTA, transductants were plated on LB agar plates containing kanamycin. After incubation for $18 \mathrm{~h}$ at $37^{\circ} \mathrm{C}$, colonies were replicated on LB agar plates containing kanamycin and the chromogenic substrate for $\beta$-galactosidase, X-Gal (Miller, 1972). Duplicate plates were incubated aerobically and anaerobically. After anaerobic growth the plates were placed at $4{ }^{\circ} \mathrm{C}$ under aerobic conditions for $30 \mathrm{~min}$ to allow oxidation of indole produced by hydrolysis of X-Gal during growth. Colonies that appeared to produce more $\beta$ galactosidase under anaerobic conditions (dark blue on $\mathrm{X}$ Gal) were selected for further studies. $\beta$-Galactosidase assays were performed in vitro as described by Miller (1972) on cultures grown under aerobic and anaerobic conditions to mid-exponential phase $\left(\mathrm{OD}_{600}=0 \cdot 2\right)$.

Clones regulated by oxygen availability were characterized as follows. The outer-membrane-enriched fraction was obtained as described by Contreras et al. (1995b) and proteins were analysed by SDS-PAGE in $12.5 \%$ polyacrylamide slabs using the procedure of Laemmli (1970) as modified by Lobos $\&$ Mora (1991). Motility was examined by stabbing into semisolid MIO medium (Difco).

Genetic techniques. Transductions were performed by using the high-transducing phage P22 HTint as described by Maloy (1990). The approximate chromosomal location of MudJ insertions was determined by the method of Benson \& Goldman (1992). This mapping technique is based on a set of S. typhimurium strains carrying locked-in Mud-P22 prophages in different locations on their chromosome. To use this technique, the MudJ insertions were first moved to $S$. typhimurium strain MST1 by transformation with linear fragments of chromosomal DNA from the mutants. The method used was based on the one described by Russell et al. (1989) and modified by N. Bossi \& L. Bossi (Centre de Génétique Moléculaire, CNRS, France; personal communication). Electroporation was performed as described by O'Callaghan \& Charbit (1990).

Invasion and intracellular proliferation assays. To measure invasion and intracellular proliferation of S. typhi strain Ty2 and its derivatives with oxygen-regulated operon fusions in HEp-2 epithelial cells, an in vitro assay based on the method described by Lissner et al. (1983) was used. Approximately $5 \times 10^{6}$ c.f.u. $(100 \mu$ l) bacteria grown to mid-exponential phase were centrifuged, resuspended in $100 \mu$ l DMEMFS (Dulbecco's modified Eagle medium supplemented with $10 \%, \mathrm{v} / \mathrm{v}$, foetal bovine serum) and added to six wells containing cell monolayers at a ratio of 10:100 bacteria per cell. After incubation for $1 \mathrm{~h}$ in a $10 \% \mathrm{CO}_{2} / 90 \%$ air atmosphere to allow for bacterial entry into the cells, monolayers were washed twice with phosphate-buffered saline (PBS: $\mathrm{NaCl}, 0.8 \%$, w/v; $\mathrm{KCl}$, $0.02 \%$, w/v; $\mathrm{Na}_{2} \mathrm{HPO}_{4} .2 \mathrm{H}_{2} \mathrm{O}, 0.13 \%$, w/v; $\mathrm{KH}_{2} \mathrm{PO}_{4}$, $0.02 \%, \mathrm{w} / \mathrm{v})$, and then $100 \mu \mathrm{L}$ DEMFS containing gentamicin $\left(250 \mu \mathrm{g} \mathrm{ml}^{-1}\right)$ was added to each well and the plates were incubated for $2 \mathrm{~h}$ to kill any remaining extracellular bacteria. The medium was removed and the cells were washed twice with PBS. Fresh medium containing gentamicin $\left(25 \mu \mathrm{g} \mathrm{ml}^{-1}\right)$ was added and cells from three wells were lysed with sodium deoxycholate $(0.5 \%, \mathrm{w} / \mathrm{v}$, in PBS $)$. The number of intracellular bacteria (c.f.u. at $t_{0}$ ) was determined by plating onto LB agar plates. The remaining three wells were incubated for $20 \mathrm{~h}$ to allow intracellular proliferation. The monolayers were then lysed and bacteria were counted (c.f.u. at $t_{20}$ ). Quantitative invasion assay results were calculated as follows: 
Invasion index $=\frac{100 \times \text { (c.f.u. intracellular at } t_{0} / \text { c.f.u. added) mutant }}{\text { (c.f.u. intracellular at } t_{0} / \text { c.f.u. added) parental }}$

Proliferation index $=$

$100 \times$ (c.f.u. intracellular at $t_{20} /$ c.f.u. intracellular at $t_{0}$ ) mutant

(c.f.u. intracellular at $t_{20} /$ c.f.u. intracellular at $t_{0}$ ) parental

\section{RESULTS}

Fusions in genes involved in anaerobic respiration are required for $\mathbf{S}$. typhi proliferation within epithelial cells

From a collection of 12346 random MudJ insertion mutants of $S$. typhi we had previously selected 25 mutants which were shown, by $\beta$-galactosidase measurements in vitro, to contain fusions in genes whose expression was induced during anaerobic growth (Contreras et al., 1995a). Three of the mutants, which were found to be impaired in invasiveness and proliferation within HEp-2 cells (Table 1), are further characterized in this work.

We confirmed that the impaired abilities to invade epithelial cells exhibited by the mutants were linked to

Table 1. Anaerobic induction of $\beta$-galactosidase activity and interactions of $S$. typhi mutants with HEp-2 cells

\begin{tabular}{|lcrrrr|}
\hline Strain & $\begin{array}{c}\text { Invasion } \\
\text { index }\end{array}$ & $\begin{array}{c}\text { Proliferation } \\
\text { index }\end{array}$ & \multicolumn{2}{c|}{$\boldsymbol{\beta}$-Galactosidase activity } \\
\cline { 5 - 6 } & & & $+\mathrm{O}_{2}$ & $-\mathrm{O}_{2}$ & $-\mathrm{O}_{2} /+\mathrm{O}_{2}$ \\
\hline Ty2 & 100 & 100 & 0 & 0 & - \\
DD46 & 3 & 10 & 363 & 1968 & $5 \cdot 4$ \\
JJ3 & 66 & 47 & 477 & 1841 & $3 \cdot 9$ \\
NN19 & 37 & 26 & 1201 & 2520 & $2 \cdot 1$ \\
\hline
\end{tabular}

"Bacteria were grown under anaerobic conditions prior to assaying with the cultured cells.

$\dagger \beta$-Galactosidase activity is expressed in Miller units (Miller, 1972). Data are from one representative experiment. Each experiment was repeated at least three times.
MudJ and were not due to a secondary mutation by backcrossing each MudJ insertion into a clean $S$. typhi strain Ty2 background and selecting for the $\mathrm{Kan}^{\mathrm{r}}$ and $\mathrm{X}$ $\mathrm{Gal}^{+}$phenotype. Transformants showed an invasiondefective phenotype and anaerobic induction of $\beta$ galactosidase activity similar to the original MudJ insertion mutant (data not shown). Based upon Southern blot analysis, all the mutants described in this study contain single Mud J chromosomal insertions (Contreras et al., 1994).

To investigate whether the fusions in mutants $\mathrm{JJ} 3$, NN19 and DD46 occurred in genes involved in anaerobic metabolism, the effect of sugars and alternative electron acceptors was studied. When the mutants were grown in $\mathrm{E}$ medium supplemented with glucose, generation times were similar to those in complex media (data not shown). The $\beta$-galactosidase levels of the mutants were similar under each of the anaerobic growth conditions tested (Table 2). Mutants JJ3 and NN19 were unable to grow in E medium supplemented with glycerol and nitrate. Because $S$. typhi cannot ferment glycerol anaerobically, growth in this medium must be sustained from nitrate respiration. These results suggest that these mutants lack nitrate reductase activity. Mutant DD46 did not grow in E medium supplemented with glycerol and either nitrate or fumarate as the terminal electron acceptor (Table 2). In addition, we observed that the three mutants, as well as the wild-type strain, were unable to grow in E medium supplemented with glycerol and dimethylsulphoxide, suggesting that S. typhi, in contrast to S. typhimurium and $E$. coli, lacks dimethylsulphoxide reductase activity.

\section{Mutants defective in anaerobic respiration are chlorate resistant}

To confirm that mutants JJ3, NN19 and DD46 were defective in nitrate reductase activity they were examined for their response to chlorate. Chlorate is reduced by nitrate reductase to yield a toxic product. Therefore, those mutants that are deficient in nitrate reductase activity are chlorate resistant under anaerobic conditions (Stewart \& MacGregor, 1982; Stewart,

Table 2. Effect of culture medium on $\beta$-galactosidase activity of anaerobically induced operon fusions

Values are expressed as $\beta$-galactosidase activity in Miller units (Miller, 1972). Cultures were grown under anaerobic conditions in LB or E medium with the supplements indicated. Data are from one representative experiment. Each experiment was repeated at least three times.

\begin{tabular}{|lcccccc|}
\hline Strain & LB & E+glucose & $\begin{array}{c}\text { E+glucose } \\
\text { + nitrate }\end{array}$ & $\begin{array}{c}\text { E+ glucose } \\
\text { +fumarate }\end{array}$ & $\begin{array}{c}\text { E+glycerol } \\
\text { + nitrate }\end{array}$ & $\begin{array}{c}\text { E+ glycerol } \\
\text { + fumarate }\end{array}$ \\
\hline DD46 & 1626 & 1858 & 2773 & 2146 & NG & NG \\
JJ3 & 1803 & 2215 & 3304 & 2596 & NG & 2584 \\
NN19 & 2069 & 2422 & 2288 & 1878 & NG & 2045 \\
\hline
\end{tabular}

NG, No growth. 
Table 3. Chlorate resistance of S. typhi strain Ty2 and anaerobically induced fusions

Cultures grown in E medium supplemented with glucose, cysteine and tryptophan were diluted and plated onto $\mathrm{E}$ agar plates with glucose, cysteine and tryptophan (") or with glucose, cysteine and tryptophan, supplemented with nitrate and chlorate $(\dagger)$. Plates were incubated under anaerobic conditions for $48 \mathrm{~h}$.

\begin{tabular}{|lccc|}
\hline Strain & $\begin{array}{c}\text { C.f.u. without } \\
\text { chlorate }^{*}\end{array}$ & $\begin{array}{c}\text { C.f.u. with } \\
\text { chlorate }\end{array}$ & $\begin{array}{c}\text { Percentage } \\
\text { survival }\end{array}$ \\
\hline Ty2 & $1.5 \times 10^{8}$ & $3.9 \times 10^{3}$ & 0.003 \\
DD46 & $3.4 \times 10^{9}$ & $2.2 \times 10^{8}$ & 6.5 \\
JJ3 & $2.7 \times 10^{9}$ & $3.0 \times 10^{8}$ & 11.0 \\
NN19 & $3.9 \times 10^{9}$ & $8.0 \times 10^{6}$ & $0 \cdot 2$ \\
\hline
\end{tabular}

1988). As shown in Table 3, the mutants were $10^{2}-10^{3}$ times more resistant to chlorate than the parental strain.

Lack of nitrate reductase activity leading to chlorate resistance is often caused by mutations in $c h l(\mathrm{~mol})$ loci, which are implicated in the synthesis, insertion or processing of molybdenum cofactor (Stewart \& MacGregor, 1982; Stewart, 1988). Therefore, we tested the effect of molybdenum on the growth of the mutants on glycerol and nitrate medium. Two of the mutants were unaffected by molybdenum, but growth of mutant NN19 was restored when cultured in E medium with glycerol and nitrate supplemented with sodium molybdate, the doubling time being similar to that of the parental strain (Fig. 1). This result suggests that the fusion in mutant NN19 could be in the modC (chlD) gene, involved in the active transport of molybdenum (Johann \& Hinton, 1987; Miller et al., 1987; Scott \& Amy, 1989). In E. coli, mod mutants are unique in that the effect of the mutation can be suppressed by an increase in the molybdate concentration in the medium (Glaser \& DeMoss, 1971; Sperl \& DeMoss, 1975; Stewart \& MacGregor, 1982).

\section{MudJ insertions map to 17-19 min and 67-69 min regions of $S$. typhimurium chromosome}

It has been previously reported that mutations in the $E$. coli nitrate reductase structural genes (the $c h l C$ locus or narG operon) do not result in a chlorate-resistant phenotype (Glaser \& DeMoss, 1971; Stewart \& MacGregor, 1982). Accordingly, when we transduced each mutant strain with a P22 lysate propagated on $S$. typhimurium strain TT10269 (chlC:: Tn10) no replacement of the $\operatorname{Kan}^{\mathrm{r}}$ phenotype with a $\mathrm{Tet}^{\mathrm{r}}$ phenotype was found, indicating that MudJ fusions were not within the chlC locus.

The approximate chromosomal location of MudJ insertions was determined with the aid of strains carrying Mud-P22 insertions at defined positions on the S. typhimurium chromosome. The MudJ insertions mapped to the 17-19 min region (mutants NN19 and
JJ3) and 67-69 min region (mutant DD46) of the $S$. typhimurium chromosome.

\section{The oxrA mutation affects expression of $\beta$-galactosidase from operon fusions}

The S. typhimurium oxrA ( $f n r$ ) gene product is a positive regulator of the anaerobically inducible genes, similar to the E. coli Fnr protein (Strauch et al., 1985). To determine the effect of an oxrA mutation on the fusions studied in this work, we transduced an $\operatorname{oxr} A 2:: \operatorname{Tn} 10$ insertion from S. typhimurium strain MST2970 into each mutant. In the case of mutants JJ3 and NN19, the $\operatorname{oxr} A$ mutation reduced expression of $\beta$-galactosidase under both aerobic and anaerobic conditions. However, the anaerobic induction ratio remained almost unaffected (Table 4), suggesting that other regulatory gene(s) are functional in $S$. typhi. The $\operatorname{oxr} A$ mutation clearly affected expression of $\beta$-galactosidase from mutant DD46, reducing the ratio of anaerobic induction to less than twofold (Table 4). The oxrA mutation had no additional effect on expression of the three fusions when the mutants were grown anaerobically in nitratesupplemented media; the $\beta$-galactosidase levels remained similar to those measured in media without nitrate under anaerobic conditions (Table 4).

To determine the regulatory effect of the oxrA gene on the expression of the $c h l C$ gene in S. typhi, a strain carrying an $\operatorname{oxr} A$ mutation and a $c h l C:$ : MudA fusion was constructed. As shown in Table 4, the oxrA mutation reduced expression of $\beta$-galactosidase under both aerobic and anaerobic conditions. However, the anaerobic induction ratio was enhanced about twofold (Table 4).

\section{The oxrA mutation suppresses the invasion/proliferation defect of the anaerobically induced mutants}

To evaluate the functional consequences of the $\operatorname{oxr} A$ mutation, we assayed the mutants ability to enter into and proliferate within HEp-2 cells. Unexpectedly, the $\operatorname{oxr} A$ mutation restored the capacity of the anaerobically induced mutants to invade epithelial cells (Table 5). Furthermore, our results suggest a potentiation of the invasiveness of the mutants. This effect was also observed with an oxrA derivative of the wild-type strain. These results indicate that the oxrA gene enhances both invasion and proliferation of $S$. typhi, and that these effects are independent of the three mutations characterized in this study. The reasons for the effect of the oxrA gene are currently being investigated.

\section{Anaerobic growth induces synthesis of membrane proteins}

It has been reported that chlorate-resistant mutants of E. coli have a complex phenotype (Graham et al., 1980). The pleiotropic nature of such mutants has been proposed to result from alterations in the structure of the membrane (MacGregor \& Schnaitman, 1971). 


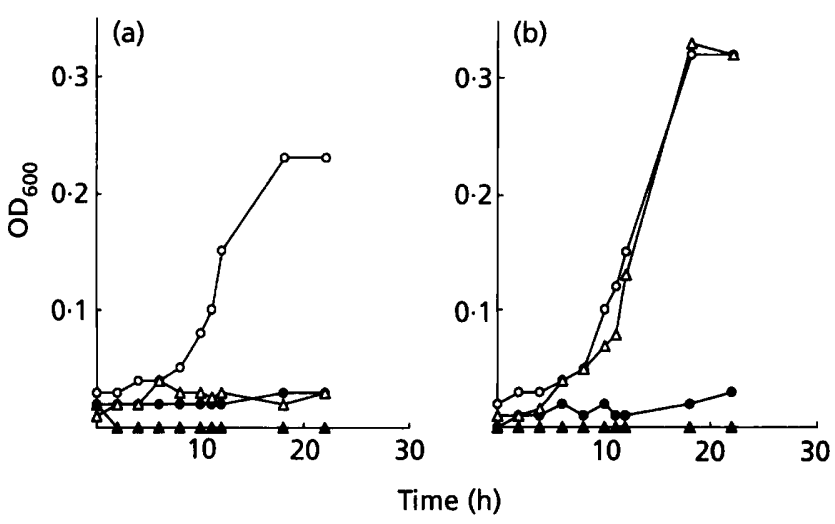

Fig. 1. Effect of the addition of molybdate on the anaerobic growth of S. typhi strain Ty2 (O) and chlorate-resistant mutants DD46 (A), JJ3 (O) and NN19 ( $\triangle)$. Bacteria were grown in minimal E medium supplemented with glycerol and $\mathrm{NaNO}_{3}$ as described in Methods. (a) No additions; (b) with the addition of $1 \mathrm{mM} \mathrm{Na}_{2} \mathrm{MoO}_{4}$.

Electrophoretic analysis of membrane fractions showed that anaerobic growth strongly induced the synthesis of two proteins with apparent molecular masses of 41 and $28.5 \mathrm{kDa}$ in the wild-type strain. On the other hand, a protein of $39.7 \mathrm{kDa}$ was repressed (Fig. 2, lane C). The addition of nitrate to the growth medium caused the induction of a $134.8 \mathrm{kDa}$ protein (Fig. 2, lane D). The latter protein band appeared in the membrane fraction of mutants DD46 and JJ3 when grown anaerobically, both in the absence and in the presence of nitrate (Fig. 2, lanes I, J, O and P), but it was not synthesized by mutant NN19 under any growth condition tested (Fig. 2, lanes $\mathrm{K}-\mathrm{M})$. In all the mutants a protein band with an apparent molecular mass of $118.5 \mathrm{kDa}$ was visible in the
Table 5. Effect of an oxrA mutation on invasion and proliferation of S. typhi strain Ty2 and anaerobically induced fusions

Data are from one representative experiment. Each experiment was done in triplicate and repeated at least three $\left({ }^{*}\right)$ or six $(\dagger)$ times.

\begin{tabular}{|lcc|}
\hline Strain & $\begin{array}{c}\text { Invasion } \\
\text { index }\end{array}$ & $\begin{array}{c}\text { Proliferation } \\
\text { index }\end{array}$ \\
\hline Ty2 & 100 & 100 \\
Ty2 oxr $A^{*}$ & 195 & 104 \\
DD46† & $20 \cdot 25$ & $26 \cdot 6$ \\
DD46 oxr $A^{*}$ & $232 \cdot 9$ & 215 \\
JJ3† & $25 \cdot 1$ & $24 \cdot 7$ \\
JJ3 oxr $A^{*}$ & $237 \cdot 4$ & $181 \cdot 4$ \\
NN19† & $36 \cdot 1$ & $25 \cdot 2$ \\
NN19 oxr $A^{*}$ & $195 \cdot 1$ & $144 \cdot 7$ \\
\hline
\end{tabular}

membrane fraction of anaerobically grown cells (Fig. 2, lanes I, J, L, M, O and P).

As shown in Fig. 2, another chlorate-resistant mutant (MM46) isolated by us also produced the 134.8 and $118.5 \mathrm{kDa}$ proteins when grown under anaerobic conditions (Fig. 2, lanes F and G). This mutant was not characterized further in this work because, in contrast to mutants DD46, NN19 and JJ3, it had a rough lipopolysaccharide (Contreras et al., 1995a), a fact that does not allow the use of phage P22 for transduction experiments.

Growth in semi-solid MIO medium and observation by light microscopy showed that under aerobic conditions the three mutants were motile. However, in contrast to the parental strain, all three mutants were non-motile

Table 4. Effect of oxrA on the expression of anaerobically induced operon fusions

Values are expressed as $\beta$-galactosidase activity in Miller units (Miller, 1972). Data are from one representative experiment. Each experiment was repeated at least three times.

\begin{tabular}{|c|c|c|c|c|c|}
\hline Strain & $+\mathrm{O}_{2}$ & $-\mathrm{O}_{2}$ & $-\mathrm{O}_{2} /+\mathrm{O}_{2}$ & $-\mathrm{O}_{2}+\mathrm{NO}_{3}^{-*}$ & $\begin{array}{c}\left(-\mathrm{O}_{2}+\mathrm{NO}_{3}^{-}\right) / \\
-\mathrm{O}_{2}^{*}\end{array}$ \\
\hline Ty2 chlC:: MudA $\dagger$ & 440 & 1258 & $2 \cdot 9$ & 1720 & $1 \cdot 4$ \\
\hline $\begin{array}{l}\text { Ty2 chlC:: MudA } \\
\text { oxrA2::Tn10 }\end{array}$ & 91 & 495 & $5 \cdot 4$ & 458 & 0.9 \\
\hline DD46 & 363 & 1968 & $5 \cdot 4$ & 1890 & $1 \cdot 0$ \\
\hline DD46 oxrA2:: $\operatorname{Tn} 10$ & 531 & 920 & $1 \cdot 7$ & 1021 & $1 \cdot 1$ \\
\hline $\mathrm{JJ} 3$ & 477 & 1841 & $3 \cdot 9$ & 1827 & $1 \cdot 0$ \\
\hline $\mathrm{JJ} 3$ oxrA2:: $\operatorname{Tn} 10$ & 390 & 1277 & $3 \cdot 4$ & 1196 & 0.9 \\
\hline NN19 & 1201 & 2520 & $2 \cdot 1$ & 3433 & $1 \cdot 4$ \\
\hline NN19 oxrA2:: $\operatorname{Tn} 10$ & 599 & 1068 & $1 \cdot 8$ & 681 & $0 \cdot 6$ \\
\hline
\end{tabular}

* Nitrate was added at $20 \mathrm{mM}$ final concentration in LB.

†S. typhi strain Ty2 chlC: : MudA was obtained by phage P22HTint transduction from S. typhimurium strain TN3038.

$¥ S$. typhi strain Ty2 chlC: : MudA oxrA2::Tn10 was obtained by phage P22HTint transduction from S. typhimurium strain MST2970 to $S$. typhi strain Ty2 chlC::MudA. 


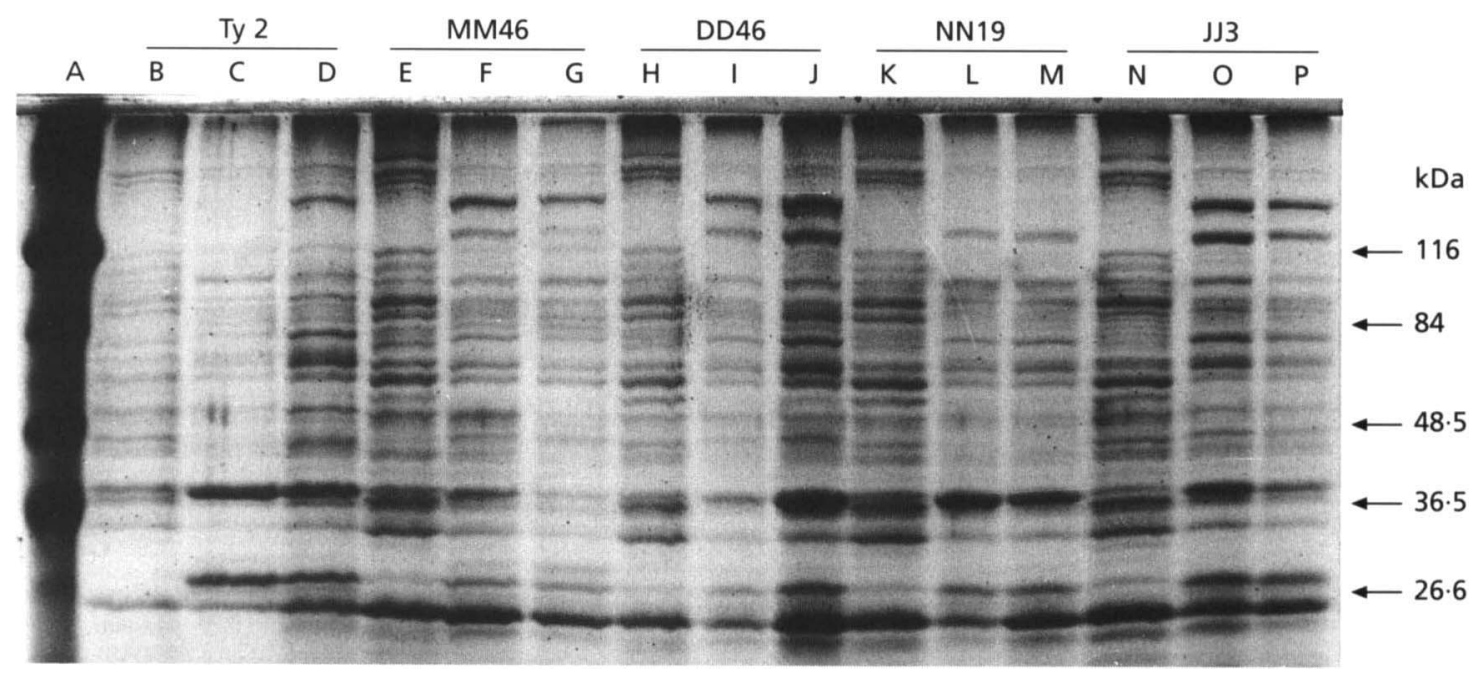

Fig. 2. SDS-PAGE analysis of outer-membrane-proteins of $S$. typhi strain Ty2 and chlorate-resistant mutants MM46, DD46, NN19 and JJ3. Lane A, molecular mass standards; lanes B, E, H, K and N, bacteria grown in LB under aerobic conditions; lanes $C, F, I, L$ and $O$, bacteria grown in LB under anaerobic conditions; lanes D, G, J, M and P, bacteria grown under anaerobic conditions in LB supplemented with $\mathrm{NaNO}_{3}$.

when grown in nitrate-supplemented LB under anaerobic conditions. Mutant NN19 was unique in that this defect was suppressed by the addition of sodium molybdate to the culture medium. By transmission electron microscopy it was observed that the non-motile bacteria were flagellated (data not shown). We believe that this result could be explained by the lack of nitrate reductase activity as this respiratory enzyme participates in the generation of proton-motive force that drives flagellar movement (Morpeth \& Boxer, 1985; Gennis \& Stewart, 1996).

\section{DISCUSSION}

As part of our interest in the identification of genes that allow $S$. typhi to survive and multiply within the human host, we have isolated a collection of anaerobically induced lac $Z$ operon fusions and characterized them with respect to their abilities to enter into and proliferate within HEp-2 epithelial cells (Contreras et al., 1995a). In the present work we have further characterized three of these anaerobically induced operon fusions whose ability to proliferate within HEp-2 cells is considerably diminished compared to the parental strain. All three mutants were unable to grow anaerobically in media containing a non-fermentable substrate (glycerol) with nitrate as the terminal electron acceptor, suggesting that they lack nitrate reductase activity. By phage P22 transduction of a chlC::Tn10 insertion from $S$. typhimurium into these mutants, we demonstrated that the MudJ insertions are not located in the $\operatorname{chlC}$ (nar) locus.

The three mutant strains showed a chlorate-resistant phenotype. Other studies have shown that virtually all chlorate-resistant mutants of $E$. coli have alterations in the synthesis or assembly of molybdenum cofactor. Five mol (formerly $c h l$ ) loci have been identified; the moaA
( $C h l A)$ and moe $(c h l E)$ gene products are involved in synthesis of molybdopterin (Pitterle \& Rajagopalan, 1989), the mod (chlD) gene product is involved in the active transport of molybdenum (Johann \& Hinton, 1987; Miller et al., 1987; Scott \& Amy, 1989), the mob $(c h l B)$ gene product is required for molybdenum processing (Johnson et al., 1991) and the mog (chlG) gene product has an unknown function (Garzón et al., 1992; Rajagopalan \& Johnson, 1992). Growth of fusion strain NN19 was restored to wild-type levels in medium supplemented with molybdate, indicating that this is probably a mod mutant. The genetic mapping results support this conclusion, namely, the MudJ insertion in mutant NN19 maps in the 17-19 min region of the chromosome and the S. typhimurium chlD $(\bmod C)$ gene has been mapped at the $18.3 \mathrm{~min}$ (Sanderson et al., 1995).

Characterization of $\operatorname{oxr} A$ derivatives of these mutants indicates that anaerobic induction of fusions NN19 and $\mathrm{JJ} 3$ is independent of the $\operatorname{oxr}$ A gene, suggesting alternative regulation of these loci. In $S$. typhimurium, in addition to the $\operatorname{oxr} A$ gene (similar to the $f n r$ gene of E. coli) and the $\operatorname{oxr} B$ gene, which are essential for the anaerobic induction of several respiratory enzymes, two other regulatory genes, oxrC and $t p p R$, have been described (Jamieson \& Higgins, 1986). The oxrA mutation, on the other hand, reduced the anaerobic induction of mutant DD46 fusion expression. This result, together with the observation that this mutant is unable to utilize both nitrate and fumarate as terminal electron acceptors anaerobically, suggests that the MudJ insertion is probably affecting a gene which is regulated by the oxrA gene and is involved in the anaerobic induction of both nitrate and fumarate reductases in S. typhi.

Examination of membrane proteins by SDS-PAGE 
showed that the addition of nitrate to wild-type S. typhi growing anaerobically in complex medium caused increased synthesis of a protein of approximately $140 \mathrm{kDa}$. This protein was present in membrane fractions of all the mutants in the absence of nitrate, with the exception of mutant NN19. It is tempting to speculate that this protein might correspond to the $\alpha$ subunit of nitrate reductase, which in $E$. coli has a molecular mass of $142 \mathrm{kDa}$ (Stewart \& MacGregor, 1982). The fact that mutant NN19 does not synthesize this protein supports this notion. In $c h l D$ mutants of $E$. coli, the band corresponding to nitrate reductase is not found in SDS-PAGE gels of membrane fractions (MacGregor \& Schnaitman, 1971). Mutant strain JJ3 might be a chlA-type mutant in which the nitrate reductase is present in the membrane fraction but does not function (MacGregor \& Schnaitman, 1971). The approximate map position within the 17-19 min region, as well as its nitrate-independent expression, is in accordance with properties reported in $C h l A$ mutants of other enterobacteria: S. typhimurium chlA (moaA) gene maps at $19.0 \mathrm{~min}$ on the bacterial chromosome (Sanderson et al., 1995) and transposon insertions in the chlA gene result in constitutive nar-lac $Z$ expression (Pascal et al., 1982). Finally, mutant DD46 might be a chlE-type mutant, which in $E$. coli barely grows in a medium containing glycerol and fumarate (Pascal \& Chippaux, 1982).

Although oxygen regulation of protein synthesis has been extensively studied in other facultative anaerobes, such as E. coli and S. typhimurium, very little is known about the effects of anaerobiosis on gene expression in $S$. typhi, due in part to the lack of adequate tools for genetic analysis in this human pathogen. In the present work we have shown that anaerobically induced genes which are involved in nitrate respiration are required for $S$. typhi invasiveness. The role of these genes in the invasion process may be an indirect one, for example, in providing the most energetically favourable metabolic processes for bacterial survival and proliferation. Alternatively, genes involved in anaerobic respiration may be coordinately regulated with genes encoding invasive capacity. Our results support recent findings, using in vivo expression technology, which show that mutations in several S. typhimurium genes involved in metabolic pathways result in reduced virulence in mice (Mahan et al., 1993; Moors \& Portnoy, 1995). This is in agreement with an expansive view of virulence determinants which includes not only those factors that cause disease, but also those functions that contribute to bacterial survival and multiplication in the host (Mekalanos, 1992; Groisman \& Saier, 1990).

\section{ACKNOWLEDGEMENTS}

We gratefully thank S. Maloy and J. Roth for providing bacterial strains. This work was supported by grants FONDECYT 1960864 and 1960255 and by a grant from Dirección de Investigación y Postgrado Universidad Católica de Chile (DIPUC). The mapping experiments were performed at the laboratory of Lionello \& Nara Bossi (Centre de
Génétique Moléculaire, CNRS, France), whose help and advice are gratefully acknowledged. The work of C.S.T. and G.C.M. at L. Bossi's laboratory was supported by the ECOSCONICYT Program.

\section{REFERENCES}

Benson, N. R. \& Goldman, B. S. (1992). Rapid mapping in Salmonella typhimurium with Mud-P22 prophages. J Bacteriol 174, 1673-1681.

Bukhari, A. Y. \& Ljungquist, E. (1977). Bacteriophage Mu: methods for cultivation and use. In DNA Insertion Elements, Plasmids and Episomes, pp. 749-756. Edited by A. Y. Bukhari, J. A. Shapiro \& S. L. Adnya. Cold Spring Harbor, NY: Cold Spring Harbor Laboratory.

Contreras, I., Obreque, V. H., Tesser, B. \& Mora, G. C. (1994). Mini-Mu technology in Salmonella typhi: isolation of stable MudJ operon fusions by cis complementation. Biol Res 27, 233-239.

Contreras, I., Obreque, V. H., Blanco, L. P., Toro, C. S. \& Mora, G. C. (1995a). Anaerobically induced Salmonella typhi genes are involved in entry to and proliferation within human-derived cell lines. South east Asian J Trop Med Public Health 26, 110-117.

Contreras, I., Muñoz, L., Toro, C. S. \& Mora, G. C. (1995b). Heterologous expression of Escherichia coli porin genes in Salmonella typhi $\mathrm{Ty} 2$ : regulation by medium osmolarity, temperature and oxygen availability. FEMS Microbiol Lett 133, 105-111.

Di Rita, V. J. \& Mekalanos, J. J. (1989). Genetic regulation of bacterial virulence. Annu Rev Genet 23, 455-482.

Dorman, C. J. (1991). DNA supercoiling and environmental regulation of gene expression in pathogenic bacteria. Infect Immun 59, 745-749.

Ernst, R. K., Dombroski, D. M. \& Merrick, J. M. (1990). Anaerobiosis, type I fimbriae and growth phase are factors that affect invasion of HEp-2 cells by Salmonella typhimurium. Infect Immun 58, 2014-2016.

Falkow, S., Isberg, R. R. \& Portnoy, D. A. (1992). The interaction of bacteria with mammalian cells. Annu Rev Cell Biol 8, 333-363.

Finlay, B. B. \& Falkow, S. (1989). Salmonella as an intracellular parasite. Mol Microbiol 3, 1833-1841.

Garzón, A., Li, J., Flores, A., Casadesus, J. \& Stewart, V. (1992). Molybdenum cofactor (chlorate-resistant) mutants of Klebsiella pneumoniae M5a1 can use hypoxanthine as the sole nitrogen source. J Bacteriol 174, 6298-6302.

Gennis, R. B. \& Stewart, V. (1996). Energy production. Respiration. In Escherichia coli and Salmonella typhimurium, Cellular and Molecular Biology, 2nd edn, pp. 217-261. Edited by F. C. Neidhardt. Washington, DC: American Society for Microbiology.

Glaser, J. H. \& DeMoss, J. A. (1971). Phenotypic restoration by molybdate of nitrate reductase activity in $c h l D$ mutants of Escherichia coli. J Bacteriol 108, 854-860.

Graham, A., Jenkins, H. E., Smith, N. H., Mandrand-Berthelot, M. A., Haddock, B. A. \& Boxer, D. H. (1980). The synthesis of formate dehydrogenase and nitrate reductase proteins in various fdh and chl mutants of Escherichia coli. FEMS Microbiol Lett 7, 145-151.

Groisman, E. A. \& Saier, M. H. (1990). Salmonella virulence: new clues to intramacrophage survival. Trends Biochem Sci 15, 30-33.

Guest, J. R. (1995). The Leeuwenhoek Lecture, 1995. Adaptation to life without oxygen. Phil Trans R Soc Lond B 350, 189-202. 
Jamieson, D. J. \& Higgins, C. F. (1986). Two genetically distinct pathways for transcriptional regulation of anaerobic gene expression in Salmonella typhimurium. J Bacteriol 168, 389-397.

Johann, S. \& Hinton, S. M. (1987). Cloning and nucleotide sequence of the chlD locus. J Bacteriol 169, 1911-1916.

Johnson, J. L., Indermaur, L. W. \& Rajagopalan, K. V. (1991). Molybdenum cofactor biosynthesis in Escherichia coli. Requirement of the chlB gene product for the formation of molybdopterin guanine dinucleotide. J Biol Chem 266, 12140-12145.

Jones, B. D. \& Falkow, S. (1994). Identification and characterization of a Salmonella typhimurium oxygen-regulated gene required for bacterial internalization. Infect Immun 6, 3745-3752.

Laemmli, U. K. (1970). Cleavage of structural proteins during the assembly of the head of bacteriophage T4. Nature 227, 680-685.

Lee, C. A. \& Falkow, S. (1990). The ability of Salmonella to enter mammalian cells is affected by bacterial growth state. Proc Natl Acad Sci USA 87, 4304-4308.

Lee, C. A., Jones, B. D. \& Falkow, S. (1992). Identification of a Salmonella typhimurium invasion locus by selection of hyperinvasive mutants. Proc Natl Acad Sci USA 89, 1847-1851.

Lin, E. C. C. \& Kuritzkes, D. R. (1987). Pathways for anaerobic electron transport. In Escherichia coli and Salmonella typhimurium, Cellular and Molecular Biology, pp. 201-221. Edited by F. C. Neidhardt. Washington, DC: American Society for Microbiology.

Lissner, C. R., Swanson, R. N. \& O'Brien, A. D. (1983). Genetic control of the innate resistance of mice to Salmonella typhimurium: expression of the Ity gene in peritoneal and splenic macrophages isolated in vitro. J Immunol 131, 3006-3013.

Lobos, S. R. \& Mora, G. C. (1991). Alteration in the electrophoretic mobility of $\mathrm{OmpC}$ due to variations in the ammonium persulfate concentration in sodium dodecyl sulfate polyacrylamide gel electrophoresis. Electrophoresis 12, 448-450.

MacGregor, C. H. \& Schnaitman, C. A. (1971). Alterations in the cytoplasmic membrane proteins of various chlorate-resistant mutants of Escherichia coli. J Bacteriol 108, 564-570.

Mahan, M. J., Slauch, J. M., Hanna, P. C., Camilli, A., Tobias, J. W., Waldor, M. K. \& Mekalanos, J. J. (1993). Selection for bacterial genes that are specifically induced in host tissues: the hunt for virulence factors. Infect Agents Dis 2, 263-268.

Maloy, S. R. (1990). Experimental Techniques in Bacterial Genetics. Boston, MA : Jones \& Bartlett Publishers.

Mekalanos, J. J. (1992). Environmental signals controlling expression of virulence determinants in bacteria. J Bacteriol 174, $1-7$.

Miller, J. H. (1972). Experiments in Molecular Genetics. Cold Spring Harbor, NY: Cold Spring Harbor Laboratory.

Miller, J. B., Scott, D. J. \& Amy, N. K. (1987). Molybdenumsensitive transcriptional regulation of the $c h l D$ locus of Escherichia coli. J Bacteriol 169, 1853-1860.

Miller, J. J., Mekalanos, J. J. \& Falkow, S. (1989). Coordinate regulation and sensory transduction in the control of bacterial virulence. Science 243, 916-922.

Moors, M. A. \& Portnoy, D. A. (1995). Identification of bacterial genes that contribute to survival and growth in an intracellular environment. Trends Microbiol 3, 83-85.

Morpeth, F. F. \& Boxer, D. H. (1985). Kinetic analysis of res- piratory nitrate reductase from Escherichia coli K12. Biochemistry 24, 40-46.

O'Callaghan, D. \& Charbit, A. (1990). High efficiency transformation of Salmonella typhimurium and Salmonella typhi by electroporation. Mol Gen Genet 223, 156-158.

Pascal, M. C. \& Chippaux, M. (1982). Involvement of a gene of the chlE locus in the regulation of the nitrate reductase operon. $\mathrm{Mol}$ Gen Genet 185, 334-338.

Pascal, M. C., Burini, J. F., Ratouchniack, J. \& Chippaux, M. (1982). Regulation of the nitrate reductase operon: effects of mutations in chlA, B, D and E genes. Mol Gen Genet 188, 103-106.

Pitterle, D. M. \& Rajagopalan, K. V. (1989). Two proteins encoded at the chlA locus constitute the converting factor of Escherichia coli chlA1. J Bacteriol 171, 3373-3378.

Poole, R. K. \& Ingledew, W. J. (1987). Pathways of electrons to oxygen. In Escherichia coli and Salmonella typhimurium, Cellular and Molecular Biology. pp. 170-200. Edited by F. C. Neidhardt. Washington, DC: American Society for Microbiology.

Rajagopalan, K. V. \& Johnson, J. L. (1992). The pterin molybdenum cofactors. J Biol Chem 267, 10199-10202.

Russell, C. B., Thaler, D. S. \& Dahlquist, F. W. (1989). Chromosomal transformation of Escherichia coli recD strains with linearized plasmids. J Bacteriol 171, 2609-2613.

Sanderson, K. E., Hessel, A. \& Rudd, K. E. (1995). Genetic map of Salmonella typhimurium, edition VIII. Microbiol Rev 59, 241-303.

Schiemann, D. A. \& Shope, S. R. (1991). Anaerobic growth of Salmonella typhimurium results in increased uptake by Henle 407 epithelial and mouse peritoneal cells in vitro and repression of a major outer membrane protein. Infect Immun 59, 437-440.

Scott, D. H. \& Amy, N. K. (1989). Molybdenum accumulation in chlD mutants of Escherichia coli. J Bacteriol 171, 1284-1287.

Sperl, G. T. \& DeMoss, J. A. (1975). chlD gene function in molybdate activation of nitrate reductase. J Bacteriol 122, 1230-1238.

Spiro, S. \& Guest, J. R. (1991). Adaptive responses to oxygen limitation in Escherichia coli. Trends Biochem Sci 16, 310-314.

Stewart, V. (1988). Nitrate respiration in relation to facultative metabolism in enterobacteria. Microbiol Rev 52, 190-232.

Stewart, V. (1993). Nitrate regulation of anaerobic respiratory gene expression in Escherichia coli. Mol Microbiol 9, 423-434.

Stewart, V. \& MacGregor, C. H. (1982). Nitrate reductase in Escherichia coli K-12: involvement of chlC, chlE, and chlG loci. J Bacteriol 151, 788-799.

Strauch, K. L., Lenk, J. B., Gamble, B. L. \& Miller, C. G. (1985). Oxygen regulation in Salmonella typhimurium. J Bacteriol 161, 673-680.

Tartera, C. \& Metcalf, E. S. (1993). Osmolarity and growth phase overlap in regulation of Salmonella typhi adherence to and invasion of human intestinal cells. Infect Immun 61, 3084-3089.

Tartera, C., van der Sluijs, A. \& Metcalf, E. S. (1993). Environmental regulation of adherence and invasion of $S$. typhi. Abstracts of the 93rd General Meeting of the American Society for Microbiology, Abstract B80.

Received 8 October 1996; revised 19 March 1997; accepted 27 March 1997. 